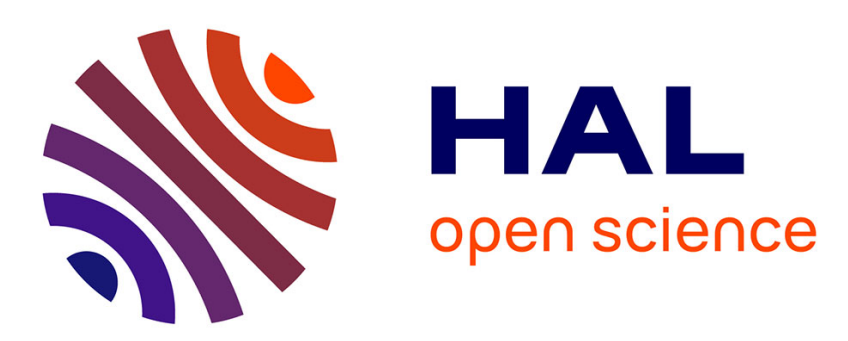

\title{
Characterization of organic matter in the Oligocene (Chattian) turbiditic fine grained deposits, offshore Angola
}

Isabelle Deniau, Jean-Robert Disnar, François Baudin, Jean-Pierre Houzay

\section{- To cite this version:}

Isabelle Deniau, Jean-Robert Disnar, François Baudin, Jean-Pierre Houzay. Characterization of organic matter in the Oligocene (Chattian) turbiditic fine grained deposits, offshore Angola. Organic Geochemistry, 2010, 41 (2), pp.135-145. 10.1016/j.orggeochem.2009.11.004 . insu-00448299

\section{HAL Id: insu-00448299 \\ https://hal-insu.archives-ouvertes.fr/insu-00448299}

Submitted on 19 Jan 2010

HAL is a multi-disciplinary open access archive for the deposit and dissemination of scientific research documents, whether they are published or not. The documents may come from teaching and research institutions in France or abroad, or from public or private research centers.
L'archive ouverte pluridisciplinaire HAL, est destinée au dépôt et à la diffusion de documents scientifiques de niveau recherche, publiés ou non, émanant des établissements d'enseignement et de recherche français ou étrangers, des laboratoires publics ou privés. 
Characterization of organic matter in the Oligocene (Chattian)

turbiditic fine grained deposits, offshore Angola

Isabelle DENIAU $^{\mathrm{a}, \mathrm{b}}$, Jean-Robert DISNAR ${ }^{\mathrm{a},{ }^{*}}$, François BAUDIN $^{\mathrm{b}}$, Jean-Pierre HOUZAY ${ }^{\mathrm{c}}$

${ }^{a}$ Institut des Sciences de la Terre d'Orléans, Université d'Orléans/CNRS/Université François Rabelais - Tours (UMR 6113), Campus Géosciences, 1A Rue de la Férollerie, 45071 Orléans Cedex 2, France

${ }^{\mathrm{b}}$ UPMC - Univ. Paris 06, CNRS-UMR 7072 Tectonique, Equipe Evolution et Modélisation des Bassins Sédimentaires, case 117, 4 place Jussieu 75252 Paris Cedex 05, France

${ }^{\mathrm{c}}$ TOTAL, Fluids and Geochemistry Department, Centre Scientifique et Technique, Avenue Larribau, 64018 Pau Cedex, France

\section{ABSTRACT}

Variations in the abundance and gross composition of the organic matter (OM) content of fine grained turbiditic Chattian sediments off Angola were explored with Rock-Eval pyrolysis of 216 core samples from 4 wells. The study revealed that the $\mathrm{OM}$ of the sediments is immature but is present in sufficient abundance [ $>1 \%$ total organic carbon (TOC)] and with a good enough quality [hydrogen index (HI) around $185 \mathrm{mg}$ hydrocarbon/g TOC on average] to constitute a potential source rock. A deeper insight into the composition of the OM was provided by the extraction and analysis of the kerogen from 15 samples. These kerogen samples were submitted to visual inspection and the counting of organic particles under the microscope (palynofacies analysis), elemental analysis and pyrolysis-gas chromatographymass spectrometry. Although individually the various observations did not provide evidence clearly diagnostic of the origin of the $\mathrm{OM}$, they confirm that it has a mixed marine-terrestrial origin, a notable part of the terrestrial contribution very probably originating from leaves. The good buoyancy of the OM and its richness in lipid components might explain the spreading of terrestrial OM over a large area and its relatively good oil potential.

Keywords: South-East Atlantic, Turbidites, Kerogen, On-line pyrolysis, Biomarkers, Palynofacies

\footnotetext{
* Corresponding author.

Tel : $(+33)(0) 2.38 .41 .73 .56$

- fax : (+33) (0)2.38.41.73.08.

E mail address : Jean-Robert.Disnar@univ-orleans.fr (J.-R. Disnar).
} 


\section{Introduction}

Deep water, sandy marine sediments have drawn the attention of the scientific community, for both economic and academic reasons. First, siliciclastic turbidites represent huge volumes of sediments which have a particular interest for hydrocarbon production, as deep water sandy facies may be potential oil reservoirs (Fetter et al., 2009; Mansurberg et al., 2008). Second, they are of interest for understanding sediment transport processes from continent to deep sea basins. In contrast to sandy facies, fine grained turbidites have been less studied although they are particularly well developed as levees of submarine fan valleys (Stow et al., 2001). They are also closely associated with the turbiditic sandy reservoirs and can act as seals in a petroleum system. These marine shales are also of importance for the transfer and deposition of OM from continental margins to deep-sea basins by turbidity currents. However, turbidite emplacement is discontinuous and produces layers of sediment in which OM quantity, type and diagenesis are heterogeneous (Cowie et al., 1995; Meyers et al., 1996; Watanabe and Akiyama, 1998; Lindblom and Järnberg, 2004).

Organic geochemists have made various attempts to quantify the terrestrial contribution to the organic content of marine sediments (see Benner, 2004 or Burdige, 2005 for a review). These studies show that the terrestrial component of the organic content of marine sediments may be significant even in remote regions of the ocean. The terrestrial organic carbon contribution in marine sediments related to deep sea fans, has, however, only given rise to a relatively limited amount of work. Nevertheless, recent work by Holtvoeth et al. (2001) and Cooke et al. (2008) explored delivery of land-derived organic matter to near-modern Congo fan sediments.

In the present study, detailed organic geochemical characterization has been conducted with a set of samples from the Chattian interval off Angola in order to determine the proportion and state of preservation of terrestrial OM in these facies.

\section{Geological setting}

The Congo basin is the central of a series of continental shelf basins extending in West Africa from the edge of the Niger delta in Cameroon to the Walvis ridge near the Angola-Namibia border. This string of basins together forms the "Aptian salt basin" (Edwards and Bignell, 1988) and as such were recently grouped as the West-Central Coastal Province (Brownfield and Charpentier, 2006). The sedimentary series of the Congo basin shows the three classical 
tectonic stages of passive margins: pre-rift continental deposits (Late Proterozoic to Late Jurassic), syn-rift lacustrine deposits (Lower Cretaceous), and post-rift unit with a large accumulation of salt (middle Aptian) covered by a thick marine succession (Albian to present).

Since the LateCretaceous, terrigenous sediments have predominantly accumulated because of (i) the global fall in sea level during the Cenozoic, (ii) on-land structural deformation and uplift increasing bed-load transport in rivers and (iii) a humid climate in the drainage area. All these factors resulted in the initiation of large turbiditic systems from the Eocene to the present.

At the Eocene-Oligocene transition, a major erosional event known as the base Oligocene unconformity has been identified (Séranne et al., 1992). This erosive surface, well-developed on the shelf, may be the result of global sea level fall in response to the onset of Antarctic glaciation. This major unconformity is overlain by the overall westwards progradation of deltaic sediments of the Malembo Formation (Oligocene to present). The discharge from an ancestral Congo-Zaire river associated with short-term sea level changes induced the deposition of extensive turbiditic facies. Oligocene deposits are primarily composed of channel-levee complexes stacked vertically and laterally. The Chattian turbiditic system is characterized by well developed external levees, built during sediment transportation inside the channel axis (by-passing of coarse sediments), as the mud fraction is progressively dragged out of the turbiditic flow and feeds plumes and overspills (Lopez, 2001; Broucke et al., 2004).

They were deposited as amalgamated or stacked turbidite channels and sand bodies in delta, pro-delta and basin-floor-fan settings and are interbedded with marine shales.

The post-salt units of the Congo were gradually deformed by gravity tectonics in response to the differential subsidence of the basin and to the increase in sediment load. Fig. 1 illustrates a schematic cross section of the Southern Congo basin (offshore Angola), showing the salt tectonic style with (i) an upslope extensional domain characterized by normal faults, (ii) a central transitional domain characterized by huge diapirs, and (iii) a downslope compressional domain of thrust faults and accumulation of salt near the transition between the continental and oceanic crusts.

Since the middle of the 1990s, oil industry has had much interest in the central transitional domain because Oligocene to Miocene turbiditic deposits provide the reservoirs for huge offshore discoveries (Fig. 2). For instance, the Girassol oil field lies $150 \mathrm{~km}$ off the coast of Angola, between Soyo and Luanda, beneath $1400 \mathrm{~m}$ water depth (Fig. 2). This field, 
discovered in April 1996 and developed since 1998, is made up of extremely permeable Oligocene sand reservoirs, containing high quality crude oil and resulting in good well productivity. Since this discovery, several similar Oligocene sandy reservoirs have been discovered and developed, such as the Cravo and Lirio oil fields (Fig. 2). Most of these sandy reservoirs correspond to the filling of submarine channels and are interbedded with marine shales acting as seals.

Characterization of the OM preserved in these shaly facies was the goal of the present study. To the best of our knowledge, information about the nature of the $\mathrm{OM}$ in these shaly facies is lacking. We provide here insight into its nature and distribution of $\mathrm{OM}$ in the Chattian turbiditic fine-grained deposits, which represent huge volumes of sediment.

\section{Material and methods}

\subsection{Samples}

Fine-grained sediments (216 samples in toto) were collected from cored intervals in four wells (Table 1). A total of $240 \mathrm{~m}$ were sampled, with an average spacing between samples varying from 0.6 to $1.7 \mathrm{~m}$. The shaly and silty samples were hard, thickly laminated and with a texture indicative of low permeability, suggesting minimum risk of contamination by the oil-based mud used during drilling. In the laboratory, the samples were cleaned to eliminate surfaces that could have been affected by alteration or oil impregnation. Chips were cut and dried in an oven at $75^{\circ} \mathrm{C}$ for $24 \mathrm{~h}$, before being pulverized in a rotating disc mill.

\subsection{Methods}

Information on the quantity, type and thermal maturity of the bulk OM was obtained from Rock-Eval pyrolysis using both an Oil Show Analyser and a Rock-Eval 6 Turbo device (Vinci Technologies) under standard conditions (for details see Espitalié et al., 1985, 1986; Peters 1986; Lafargue et al., 1998; Béhar et al., 2001). TOC content (wt\%), HI, mg hydrocarbon (HC)/g TOC), oxygen index (OI, mg $\mathrm{CO}_{2} / \mathrm{g}$ TOC) and $\mathrm{T}_{\max }\left({ }^{\circ} \mathrm{C}\right)$ were determined.

For bitumen extraction the powdered bulk rock was extracted with a mixture of $\mathrm{MeOH} / \mathrm{CH}_{2} \mathrm{Cl}_{2}(1: 1 \mathrm{v} / \mathrm{v} 3 \times 15 \mathrm{~min}$ each $)$ at room temperature using an ultrasonic vat at 65 $\mathrm{Hz}$ ). The bitumen was recovered by centrifugation and the solvent was evaporated under vacuum.

The kerogen was isolated from 15 samples selected to cover the larger range of palynofacies composition as possible among the numerous samples studied by Pirious (2006). These 
kerogens were isolated using the classical procedure described by Durand and Nicaise (1980), including extraction with organic solvent after acid attack, under the same conditions as for bitumen extraction. The elemental composition $(\mathrm{C}, \mathrm{H}, \mathrm{O}, \mathrm{N}, \mathrm{S}, \mathrm{Fe})$ of the kerogen concentrates was determined as follows: thermal conductivity measurements were used for $\mathrm{C}$, $\mathrm{H}$ and $\mathrm{N}$, while coulometry was used for $\mathrm{O}$ measurements. $\mathrm{S}$ was determined via oxidation followed by quantitative coulometry of $\mathrm{SO}_{2}$; for $\mathrm{Fe}$, demineralization was carried out with a mixture of $\mathrm{HNO}_{3}$ and $\mathrm{H}_{2} \mathrm{SO}_{4}$ and $\mathrm{Fe}$ content was determined using atomic absorption spectrophometry.

Gas chromatography-mass spectrometry (GC-MS) analysis was performed with a Thermo-Finnigan TRACE-Polaris GCQ gas chromatograph-mass spectrometer. The gas chromatograph was fitted with an Rtx ${ }^{\mathrm{TM}}-5$ Sil MS column $(30 \mathrm{~m}$ x $0.32 \mathrm{~mm}$ i.d., $0.25 \mu \mathrm{m}$ film thickness) with a $5 \mathrm{~m}$ guard column. The GC oven temperature programme was $40{ }^{\circ} \mathrm{C}(1 \mathrm{~min})$ to $120{ }^{\circ} \mathrm{C}$ at $30{ }^{\circ} \mathrm{C} / \mathrm{min}$, to $300{ }^{\circ} \mathrm{C}$ (hold $30 \mathrm{~min}$ ) at $3{ }^{\circ} \mathrm{C} / \mathrm{min}$. Samples were injected splitless, with the injector temperature set at $280{ }^{\circ} \mathrm{C}$. He was the carrier gas. The mass spectrometer was operated in the electron ionization (EI) mode at $70 \mathrm{eV}$ ionization energy and scanned from $\mathrm{m} / \mathrm{z} 50$ to 650 . Compounds were tentatively assigned by comparison with library (NIST) mass spectra and relative retention times. Curie point pyrolysis (CuPy)-GC-MS) was performed with a Fischer GSG flash pyrolyser directly coupled to the GC-MS system, He being used as carrier gas. The temperature for the ferromagnetic cylinder was $650{ }^{\circ} \mathrm{C}$, which allows cracking of the bulk macromolecular structure of the OM. The analyses were carried out under the same conditions as above except that the temperature programme was $50^{\circ} \mathrm{C}$ (hold $5 \mathrm{~min}$ ) to $300^{\circ} \mathrm{C}$ (hold $10 \mathrm{~min}$ ) at $4^{\circ} \mathrm{C} / \mathrm{min}$.

Thermochemolysis was carried out as described by Disnar et al. (2008). Briefly, ca. 25 mg of dried and crushed kerogen were introduced in SVL® screw cap glass tubes with $50 \mu \mathrm{L}$ of a standard solution of heptylbenzoïc acid $(21 \mu \mathrm{g} / 100 \mu \mathrm{MeOH})$ and $100 \mu \mathrm{L}$ tetramethyl ammonium hydroxide solution (TMAH; $25 \%$ in $\mathrm{MeOH}$ ). The tubes were placed open in an oven at $75^{\circ} \mathrm{C}$ for 3 to $5 \mathrm{~h}$ to evaporate excess $\mathrm{MeOH}$, cooled and closed under vacuum. They were then placed vertically in a sand bath heated at $250{ }^{\circ} \mathrm{C}$ and left for $20 \mathrm{~min}$. After cooling in ambient air, $1.5 \mathrm{ml}(\mathrm{Et})_{2} \mathrm{O}$ was introduced to extract the pyrolysis products. After solvent evaporation, the extract was diluted in 50 or $100 \mu \mathrm{CH}_{2} \mathrm{Cl}_{2}$ and analysed using GC-MS under the same conditions as described above.

The samples selected for kerogen concentrates were also prepared for palynofacies analysis using a Zeiss Axoplan microscope under different illumination modes. Neither oxidation nor the ultrasonic probe were used during processing as all the particles were of interest in this 
study and might have been selectively destroyed by such procedures. To better differentiate and count small as well as large particles, the residue was separated into two fractions. One was mounted directly on to a glass microscope slide and the other on to a slide after sieving through a $10 \mu \mathrm{m}$ sieve. Between 565 and 1050 particles were counted using a grid-ocular in order to obtain relative percentages of surface covered by each type of particle.

The classification of palynofacies has always been rather subjective (Tyson, 1995). For this study, a classification was chosen in order to obtain as much palaeoenvironment information as possible from palynofacies analysis. The following particles were identified during these quantitative investigations:

- Phytoclasts comprising all opaque and translucent land plant debris. Different subgroups could be observed within this fraction and were distinguished during counting.

- Sporomorphs comprising land derived pollen grains and spores.

- Fungal debris comprising all the filamentous segmented particles and sclerotes.

- Marine algae comprising dinoflagellate cysts and other organic-walled algae.

- Foraminiferal linings comprising the chitinous membranes of foraminifera.

- Amorphous OM (AOM) comprising all particulate organic components that appear structureless at the scale of light microscopy. Fluorescence microscopy was used to characterize the preservational state of the AOM.

\section{Results and interpretations}

Although attention was taken during sampling to avoid contamination, the results of RockEval pyrolysis clearly indicated that the oil-based mud used during drilling had partly impregnated the shales and silts. Free hydrocarbons were systematically detected in all samples with quantities around $3 \mathrm{mg} / \mathrm{g}$ of rock, as measured from the $\mathrm{S}_{1}$ peak of the RockEval instrument.

Because the Chattian rocks are immature with respect to oil generation (see below), the hydrocarbon content clearly represented contamination and should not be taken into account in the characterization of the autochthonous OM. A set of 14 samples from the GIR 117 well was extracted with a mixture of $\mathrm{MeOH} / \mathrm{CH}_{2} \mathrm{Cl}_{2}$ and re-analyzed using Rock-Eval pyrolysis. This treatment resulted in the near complete disappearance $(>91 \%)$ of the $\mathrm{S}_{1}$ peak, without any change in the other parameters $\left(S_{2}, T_{\max }\right)$. As the $S_{1}$ peak is included in the determination 
of the organic carbon content, the TOC value was corrected for the carbon associated with the $\mathrm{S}_{1}$ peak and the HI value was recalculated for all 216 analysed samples.

Seven samples of drilling-mud used in the different wells were prepared as for kerogen isolation. They did not produce any insoluble residue, providing evidence that the oil used in the mud did not alter the kerogen of the Chattian samples. In consequence, our samples can be used for organic geochemical purposes after solvent extraction and kerogen preparation.

\subsection{Bulk organic geochemical data}

\subsubsection{Rock-Eval pyrolysis}

For the four wells, the mean TOC contents (\%) are: GIR 117, 1.3\%; GIR IS3, 1.0\%; LIR 1, $1.4 \%$; CRA 1, 1.6\% (Table 2). Some of the individual samples are very rich with a TOC content reaching $4 \%$. In addition, TOC concentrations are variable with depth without any stratigraphic trend in the evolution of the organic richness, except for the GIR IS3 well, where a constant decrease in TOC is noted from the top to the base of the studied interval.

An assessment of the degree of thermal maturity reached by the Chattian rocks offshore Angola is provided by $\mathrm{T}_{\max }$ values which vary between 400 and $437^{\circ} \mathrm{C}$ (average $427^{\circ} \mathrm{C}$ ) for the four wells; Table 2). Due to the relatively small thickness of studied intervals (25 to 120 $\mathrm{m}$; Table 1), the large range in $\mathrm{T}_{\max }$ cannot be assigned to differences in $\mathrm{OM}$ maturity and is rather due to differences in OM composition, including differences in the amount of recycled and oxidized OM (see Discussion). In any case, the Chattian fine-grained sediments are immature with respect to oil generation and so have not experienced high temperature during burial.

Consequently, the type of OM could be estimated from pyrolysis data on the basis of the HI parameter. According to the range of values (31-381 mg HC/g TOC; Table 2), the OM could be classified as a mixture of Types III and II (higher HI values). The four wells display similar average values around $185 \mathrm{mg} \mathrm{HC} / \mathrm{g}$ TOC (Table 2).

\subsubsection{Elemental analysis}

Elemental analysis data obtained from kerogens (Table 3) first show that they are rather pure, the sum of organic elements being always above $87 \%$, with a maximum value of $97 \%$, except for samples GIR117-28 and GIR IS3-4 in which the total recovery is only 58\%, due to a high amount of non destroyed minerals. The TOC content comprises between 8 and $49.2 \%$ and both $\mathrm{S}$ and $\mathrm{Fe}$ are two major elements present in the concentrates, meaning that pyrite $\left(\mathrm{FeS}_{2}\right)$ is mixed with the OM. 
Using the formula of pyrite, it is possible to calculate the total pyrite content in the concentrates and consequently the organic sulfur content (Durand and Monin, 1980). The results in Table 3 show that the organic sulfur content comprises between 0 and $8 \%$ and that the pyrite content is as high as $73 \%$. The dilution effect from the pyrite has no direct influence on the measurement of other elements like $\mathrm{C}, \mathrm{H}, \mathrm{O}$ and $\mathrm{N}$. Thus, the elemental analysis data can be corrected for the pyrite content and the $\mathrm{H} / \mathrm{C}$ and $\mathrm{O} / \mathrm{C}$ atomic ratios derived for the kerogens are effectively representative of their composition (Table 3). The $\mathrm{H} / \mathrm{C}$ values are relatively homogeneous and range from 1.08 to 1.23 , thereby indicating medium aliphaticity for the kerogen. When plotted in a H/C-HI diagram, the data points for the kerogens appear well grouped around an average HI value of $345 \mathrm{mg} \mathrm{HC} / \mathrm{g}$ TOC, on the general trend defined by Espitalié et al. (1977) for such materials. In contrast, the O/C values vary between 0.21 and 0.58 and are poorly correlated with the OI values of the concentrates, which are nearly constant with an average value around $32 \mathrm{mg} \mathrm{CO} / \mathrm{g}$ TOC. This discrepancy between $\mathrm{O} / \mathrm{C}$ and OI values might be related to the presence of mineral residues, which affects the determination of the organically-bound oxygen content. In addition, the flash pyrolysis results that show a very low proportion of oxygen-compounds in the kerogen (see below) also support an overestimation of the oxygen from elemental analysis. The $\mathrm{N} / \mathrm{C}$ ratio values, which are between 0.047 and 0.027 (i.e. $\mathrm{C} / \mathrm{N}$ values between 21 and 37) are typical for terrestrial OM (Meyers, 1994). However, any algal contribution has very probably been highly degraded in the water column and the sediment, with a preferential degradation of nitrogenous components (Wakeham et al, 1997). The low molecular weight nitrogenous compounds preferentially released during degradation might have been lost in the water column or simply during the kerogen extraction, thereby excluding the use of such elemental analysis data by way of the very classical Corg/Ntot parameter so appreciated by soil scientists.

The much higher HI values found for the isolated kerogens than for bulk sediments (av. 345 vs $185 \mathrm{mg} \mathrm{HC/g}$ TOC) might be explained by a classical mineral matrix effect (Espitalié et al., 1986).

Using both van Krevelen and modified van Krevelen (HI-OI) diagrams (Fig. 3), the OM of the Chattian fine-grained sediments off Angola appears as a mixture of Type II and III according to Tissot and Welte (1984). This confirms the origin of the OM deduced from the analysis of the bulk samples.

\subsection{Palynofacies}


Palynofacies analysis indicates a strong predominance of AOM (AOM) which represents between 70 and $96 \%$ of the total particles (Figs. 4a and b). The structured particles consist almost exclusively of higher plant debris at different states of diagenetic alteration. Different types can be recognized from yellow coloured cuticles with well preserved cellular structures (Fig. 4c) to dark brown and gelified ligno-cellulose debris (Fig. 4d). Ligno-cellulose particles represent between 2 and 30\% (ave. 18\%) of total particles. Cuticles are present at a low level $(0.5$ to $9 \%)$, whereas sporomorphs are rare $(<2 \%)$. Fungal remains are frequent and may represent a few percent in some samples. Marine palynomorphs and foraminiferal linings are scarce.

The AOM particles can be classified into two main groups. The first is composed of highly fluorescent granular AOM (Figs. 4e and f). The second is represented by AOM particles generally presenting sharp contours with remains of plant fibres (Fig. 4g). This type of AOM shows a lower fluorescence, some granules included in the AOM fluorescing whereas the fibre and the remainder of the AOM show a dull fluorescence (Fig. 4h). Variations in AOM appearance probably highlight the origin of the OM (marine vs. terrestrial) but also the role of the depositional setting, i.e. intensity of oxidation.

\subsection{Molecular data (Py-GC/MS and thermochemolysis with TMAH)}

Representative pyrograms are displayed in Fig. 5. The distributions are dominated by the peaks from $n$-alkane/n-alkene doublets. However, the latter can be more clearly appreciated using selective ion detection (Fig. 6). The py-GC/MS traces also show various other compounds belonging to the following series (Fig. 5; Table 4): isoprenoids, phenols, alkylbenzenes, alkylnaphtalenes, indanes/indenes and hopanes. The distributions and the origins of the various compounds are discussed in the following section.

In a study of the kerogen from turbidites of the Madeira abyssal plain, Hoefs et al. (1998) found series of pyrolysis products very similar to those found in the present study, namely, $n$ alkane $/ n$-alkene doublet distributions extending over a large carbon number range $(<10$ to $>30$ ), alkylphenols, alkylbenzenes and other alkylated aromatics, plus isoprenoids. Except for the phenols assumed to be derived from the lignin of terrestrial plants, the authors hypothesized that all the other compounds derived from algal biopolymers. In this way, the $n$ alkanes/n-alkenes and the isoprenoids were attributed to algaenan. The latter comprises non hydrolyzable and highly aliphatic macromolecules biosynthesized by certain (micro)algae, especially Chlorophyceae and Eustigmatophyceae, and is a component of their outer cell 
walls (Largeau et al., 1984; Goth et al., 1988; Derenne et al., 1992; de Leeuw and Largeau, 1993; Gelin et al., 1996). In fact, most or even all the pyrolysis products identified can have various sources and are thus hardly diagnostic of an unequivocal biological origin. For example $n$-alkane/n-alkene distributions extending beyond $\mathrm{C}_{30}$ can also originate from cutan, a biopolymer in the cuticles of certain plants, especially species thought to be adapted of coping with severe drought (Boom et al., 2005). However, other hypotheses cannot be excluded, such as a heterogeneous polymer formed in soil by clay-catalyzed polymerization of fatty acids with humic colloids (Almendros and Sanz, 1992; Almendros et al., 1996).

Aromatic compounds are dominated by benzene and its alkylated counterparts with up to 22 $\mathrm{C}$ atoms in the side chain, but with a prevalence of short chain alkylbenzenes $\left(\mathrm{C}_{0}\right.$ with $\left.\mathrm{C}_{2}\right)$. Polyaromatic compounds are dominated by a series of naphthalenes from $\mathrm{C}_{0}$ to $\mathrm{C}_{4}$ and anthracenes and/or phenanthrenes from $\mathrm{C}_{0}$ to $\mathrm{C}_{2}$. A series of alkyl indanes and alkyl indenes are also present. The origin of all these aromatic compounds is still poorly defined. They are likely to originate from acyclic hydrocarbon cyclization and aromatization during pyrolysis (Largeau et al., 1986). They can also come from pre-existing aromatic entities in the kerogen. For example, complex mixtures of polyaromatic hydrocarbons (PAHs) observed in the pyrolysates of various kerogens were regarded as coming from highly resistant polyaromatic nuclei-containing algal biomacromolecules selectively preserved in the kerogen (Horsfield et al., 1992; Derenne et al., 1996). This second assumption which might account for the great diversity of PAHs in the pyrolysates, is supported by the presence of important deformation bands of groupings adjacent to $\mathrm{C}=\mathrm{C}$ bond, evidenced by Fourier transformed infra-red analysis of the kerogens (data not shown).

Alkylated phenols (up to $\mathrm{C}_{5}$ ) are the only oxygenated compounds detected in the pyrograms. Their abundance falls rapidly beyond the $\mathrm{C}_{2}$ compounds. Phenolic compounds with short chains are generally regarded as products of the thermal breakdown of lignin (e.g., SaizJimenez and de Leeuw, 1986) and are thus regarded as indices of a terrestrial contribution to the kerogen of the Chattian facies, in agreement with the palynofacies observations. This hypothesis can hardly hold for the phenols with a side chain longer than $\mathrm{C}_{3}$ since the lignin monomers have a phenylpropane skeleton. However, these higher homologues are present inonly low amounts, are not discussed further. The distributions of the polyaromatic compounds and phenolic compounds show few differences among the various samples.

Polycyclic alkanes of the hopane type in the range $\mathrm{C}_{27}$ to $\mathrm{C}_{30}-\mathrm{C}_{31}$ were detected in all the pyrolysates, but in very variable abundance. Hopanes assure the rigidity in the structure of the walls of bacteria and are thus regarded as bacterial markers (e.g., Ourisson et al., 1979). 
In the present case, a notable contribution to the $\mathrm{OM}$ from terrestrial plant material is supported by the thermochemolysis of two samples which effectively provided very nice distributions of $n$-fatty acid methyl esters (FAMEs: Fig. 7) highly dominated by even numbered $F A s$ in the range $\mathrm{C}_{22}$ to $\mathrm{C}_{34}$, with a mode at $n-\mathrm{C}_{28}$. These FAMEs are also accompanied by: (i) lower but still notable proportions of $n$-alkanes in the range $C_{28}$ to $C_{39}$, with a mode at $n-\mathrm{C}_{31}$ to $n-\mathrm{C}_{33}$ but only with a very slight predominance of odd-numbered homologues over their even counterparts, and (ii) even lower but still non negligible amounts of $\alpha, \omega$ diacids (as dimethylesters), with a predominance at $n-C_{31}$ to $n-C_{33}$ and a marked even/odd predominance above $n-C_{27}$. All these compounds are assumed to be typical components of the waxes that coat the outer cuticle of subaerial plant tissues and help protect them from various external physical and biological agents. Such long chain FA distributions have recently been found in coastal lagoon sediments near Rio de Janeiro in Brazil (Zink et al., 2004). The authors assumed a terrestrial plant origin but without providing any identification of its source. The higher plant origin of the compounds is also supported by the presence, among the low molecular weight thermochemolytic products, of vanillic acid, in addition of its demethoxylated counterpart, p-HO benzoic acid (compounds being under the form of methyl esters/methyl ethers). Vanillic acid is a typical degradation product of gymnosperm lignin but might also derive from the syringyl moieties of angiosperm lignin via demethoxylation. The absence of the corresponding aldehyde and ketone (i.e. vanillin and acetovanillone) suggests that the lignin suffered extensive oxidative alteration before burial.

\section{Discussion}

\subsection{OM maturity}

A low degree of maturity for the Chattian sediments is evidenced by both $\mathrm{T}_{\max }$ values and the colour of organic particles. Average $\mathrm{T}_{\max }$ values vary between 426 and $428{ }^{\circ} \mathrm{C}$ in the four wells, with a deviation between 3.53 and $5.26{ }^{\circ} \mathrm{C}$. The wider range of measured $\mathrm{T}_{\max }$ values $\left(400-437{ }^{\circ} \mathrm{C}\right.$ ) for all the samples is attributed partly to analytical errors but mostly to variations in the composition of the OM (OM) depending on its type and on the extent of the alteration it suffered during early diagenesis . In any case, average $\mathrm{T}_{\max }$ values below $430{ }^{\circ} \mathrm{C}$ indicate that the $\mathrm{OM}$ did not experience high temperatures during burial and is thus uniformly immature with respect to oil generation. This maturity assessment is also supported by the light colour of the AOM, the strong fluorescence of certain AOM flakes and the yellow colour of cuticles observed in palynofacies. This low degree of maturity is in agreement with the 
moderate burial of the Chattian sediments in that part of the Angola margin, as the studied intervals experienced around $1500 \mathrm{~m}$ of overburden sedimentation.

\subsection{OM type and origin}

An important question that remains open is the origin of the $\mathrm{OM}$ or more precisely the relative importance of the marine and terrestrial fractions since we have evidence that both contributed to the Chattian sedimentation off Angola.

Rock-Eval pyrolysis data and elemental analysis (Tables 2 and 3, Fig. 3) indicate an OM type varying between a mixed Type II and III, with highly variable but often extensive alteration of the original input as evidenced by some low HI values (whose significance is exaggerated by the strong mineral matrix effect evidenced by comparison of the HI values of the bulk sediments with those of the corresponding kerogens). Palynofacies preparations are largely dominated by AOM which is usually related to marine sources, although some terrestrial organic particles may also be "amorphised" (Tyson, 1995; Marchand et al., 2003). Fluorescence investigations can help differentiate highly fluorescencent well preserved marine OM from oxidised low fluorescent particlesof terrestrial or marine origin. Here, both fluorescent and non-fluorescent AOM co-exist.

At the present state of knowledge the various families of compounds released by on-line pyrolysis data are not adequately diagnostic to allow a clear biological origin to be assigned forthe OM. For example, the $n$-alkane/n-alkene doublets can be attributed to various kinds of resistant biopolymers of different origin (See section 4.3). However, at least two other factors should be considered: (i) the presence of well preserved labile material (of marine and/or terrestrial origin) which adds its own signature to that of the refractory constituents; e.g. for the marine material this is supported by recent work which clearly demonstrated that algal material can be preserved after settling to great depth in well-oxygenated waters (Bertrand et al., 2003; Pichevin et al., 2004); (ii) the exact nature of the terrestrial input, whose composition and quality can which differ greatly whether it is inherited from soils (and thus is mostly made up of residual humic substances) or whether it is mostly made up of woody debris (rich in cellulose and lignin) or of leaves (rich in waxy components). In an attempt at overcoming these various difficulties, we suggest interpreting the $n$-alkane/n-alkene distributions, obtained from kerogen pyrolysis, in the same way as is classically done for the free hydrocarbon distributions where it has been assumed for a long-time that the low and high molecular weight ends derive from marine and terrestrial contributions, respectively. For the terrestrial part, the assumption is supported here by the classical odd/even $n$-alkane/n- 
alkene predominance among the longer chains (i.e. $\geq n-C_{27}$ ) and additionally by the high molecular weight FAs, $n$-alkanes and diacids evidenced by thermochemolysis. Nevertheless, this assumption remains difficult to verify. Indeed, following our assumption, sample GIR IS3-29, the pyrolysis of which only revealed low molecular weight $n$-alkanes $/ n$-alkenes (predominance at $\mathrm{C}_{11}-\mathrm{C}_{17}$; Fig. 6) does not differ markedly from the other samples, namely, it is rather poor in TOC $(0.6 \%)$ but has a "normal" HI value of $222 \mathrm{mg} \mathrm{HC.g-}{ }^{1}$ TOC and, above all, it also released notable amounts of phenolic compounds, aromatics and isoprenoids upon pyrolysis (Table 4). Its palynomorph composition is made up of dark brown to black rounded amorphous particles. So, with the support of other data, the globally bimodal $n$-alkane $/ n$ alkene distributions produced upon pyrolysis of the studied kerogens provide evidence that they are made up of variable contributions of marine and terrestrial $\mathrm{OM}$, the first estimate made from these distributions having to be corrected for other factors, beginning with the degree of early diagenetic alteration suffered by both contributions.

\subsection{Organic matter sedimentation and implications for deep offshore source rocks}

The ca. $\sim 1 \%$ TOC of the Chattian sediments off Angola is significantly greater than the average TOC of $0.2 \%$ measured for Recent deep sea sediments (McIver, 1975) but is typically in the range determined by Premuzic et al. (1982) for margin sediments. This rather high value is evidently related to the high delivery of OM associated with the sedimentary systems on this part of the West African continental margin.

The studied area received both pelagic and terrigeneous inputs. The terrigeneous flux was delivered by the ancestor of the Congo-Zaire River and its submarine canyon system, whereas the autochthonous pelagic sedimentation was driven by the activity of the plume related to fluvial discharge. Depending on the intensity of one or the other of these sources, the delivery of OM has evidently varied both spatially and temporally during the Chattian. Part of this variability may result from the turbidite phenomenon itself, but the primary cause of the differences in $\mathrm{OM}$ concentration is probably the degree of export of $\mathrm{OM}$ to the sea floor and the changes in its post-depositional preservation.

This variability would suggest a mixing of OM sources with variable intensity of oxidation. Such a feature is expected for turbiditic facies in which a terrestrial contribution is mixed with the marine autochthonous OM (Watanabe and Akiyama, 1998; Lindblom and Järnberg, 2004). As supported by the high molecular weight $n$-alkane/n-alkene doublets and FAMEs evidenced respectively by py-GC/MS and thermochemolysis, the terrestrial OM seems abundant and rich in leaf-derived fragments. These particles, including cuticles, have good 
buoyancy and may thus be transported far from their source where they can mix with marine planktonic OM, leading to a homogenisation of the OM content.

The variation in organic input is primarily controlled by the depositional setting (distance from the channel, rate of sedimentation, intensity of sea surface primary productivity). After its deposition this organic mixture is still homogenised by diagenetic alteration, which is mainly oxidative, but can also develop under reducing condition as evidenced by the amount of pyrite and the proportion of hopanoids revealed by py-GC/MS.

\section{Conclusions}

TOC is the primary parameter for source rock appraisal, with a threshold of $1 \mathrm{wt} \%$ at the immature stage for potential source rocks. With an average TOC value which exceeds this threshold in almost all the studied samples (and nearly up to 4\% TOC), the Chattian finegrained turbiditic series off Angola appear to be potential source rocks. Such TOC values also indicate that, despite long distance transportation and/or deposition at rather great water depth, sediment emplacement occurred under conditions suitable for OM preservation. The high sedimentation rate during the Chattian (200m/Ma according to Broucke et al., 2004) allowed rapid burial of the sedimentary succession and the preservation of its OM content.

The second prerequisite for good petroleum source rock is the quality of the OM. Bulk geochemical parameters $\left(\mathrm{S}_{2}, \mathrm{HI}\right)$ as well as elemental analysis results indicate that the Chattian organic-rich facies have moderate oil to gas-prone potential.

Although the sedimentary overburden was not sufficient to reach the beginning of the oil window in this part of the margin, deep water shaly facies associated with sandy reservoirs should be considered as potential source rocks where they experience a higher thermal evolution in other parts of the margin. 


\section{Acknowledgements}

This project was supported, in part, by financial support from the INSU GDR Marges Program and by a post-doctoral grant from TOTAL (for I.D.). TOTAL is acknowledged for allowing sampling of their wells and for granting permission to publish this article.We also acknowledge M. Hatton and F. Savignac for their analytical help and A. Lethiers for having transforming our crude drawings into intelligible illustrations. We are also grateful to P. A Meyers and an anonymous referee for their constructive reviews of the manuscript. 


\section{References}

Almendros, G., Sanz, J., 1992. A structural study of alkyl polymers in soil after perborate degradation of humin. Geoderma 53, 79-95.

Almendros, G., Guadalix, M. E., González-Vila, F. J., Martin, F., 1996, Preservation of aliphatic macromolecules in soil humins. Organic Geochemistry 24, 651-659.

Béhar, F., Beaumont, V., De B.Penteado, H.L., 2001. Rock-Eval 6 Technology: performances and developments. Oil \& Gas Science and Technology - Revue de l'Institut Français du Pétrole 56, 111-134.

Benner, R.H., 2004. What happens to terrestrial organic matter in the ocean?. In Benner R.H, Lee C., Wakeham S.G. (Eds), new Approaches in Marine Organic Biogeochemistry; a Tribute to the Life and Science of John I. Hedges. Marine Chemistry 92, 307-310.

Bertrand, P., Pedersen, T.F., Schneider, R., Shimmield, G., Lallier-Vergès, E., Disnar, J.R., Massias, D., Villanueva, J., Tribovillard, N., Huc, A.Y., Giraud, X., Pierre, C., VenecPeyré, M.T., 2003. Organic-rich sediments in ventilated deep-sea environments: relationship to climate, sea level, and trophic changes. Journal of Geophysical Research $108,1-11$.

Boom, A., Sinninge Damsté, J.S., de Leeuw, J.W., 2005. Cutan, a common aliphatic biopolymer in cuticles of drought-adapted plants. Organic Geochemistry, 36, 595-601.

Broucke, O., Temple, F, Rouby, D., Robin, C., Calassou, S, Nalpas, T., Guillocheau, F., 2004. The role of deformation processes on the geometry of mud-dominated turbiditic systems, Oligocene and Lower-Middle Miocene of the Lower Congo basin (West African Margin). Marine and Petroleum Geology 21, 327-348.

Brownfield, M.E., Charpentier, R.R., 2006. Geology and total petroleum systems of the WestCentral Coastal Province (7203), West Africa. US Geological Survey Bulletin 2207-B, $52 \mathrm{pp}$.

Burdige, D.J., 2005. Burial of terrestrial organic matter in marine sediments; a re-assessment. Global Biogeochemical Cycles. 19, 4, GB4011, doi:10.1029/2004GB002368.

Cooke, M.P., Talbot, H.M., Wagner, T., 2008. Tracking soil organic carbon transport to continental margin sediments using soil-specific hopanoid biomarkers: A case study from the Congo fan (ODP site 1075). Organic Geochemistry 39, 965-971.

Cowie, G.L., Hedges, J.I., Prahl, F.G., De Lange, G.J., 1995. Elemental and major biochemical changes across an oxidation front in a relict turbidite: An oxygen effect. Geochimica et Cosmochimica Acta 59, 33-46. 
de Leeuw, J.W., Largeau, C., 1993. A review of macromolecular compounds that comprise living organisms and their role in kerogen, coal and petroleum formation. In: Engel, M.H., Macko, S.A. (Eds.), Organic Geochemistry - Principles and Applications. Plenum Press, New York, pp. 23-72.

Derenne, S., Metzger, P., Largeau, C., Van Bergen, P.F., Gatellier, J.P., Sinninghe Damsté, J.S., de Leeuw, J.W., Berkaloff, C., 1992. Similar morphological and chemical variations of Gloeocapsomorpha prisca in Ordovician sediments and cultured Botryococcus braunii as a response to changes in salinity. Organic Geochemistry 19, 299-313.

Derenne, S., Largeau, C., Berkaloff, C., 1996. First example of an algaenan yielding an aromatic-rich pyrolysate. Possible geochemical implications on marine kerogen formation. Organic Geochemistry 24, 617-627.

Disnar, J. R., Jacob, J., Morched-Issa, M., Lottier, N., Arnaud, F. 2008. Assessment of peat quality by molecular and bulk geochemical analysis; application to the Holocene record of the Chautagne marsh (Haute Savoie, France). Chemical Geology 254, 101-112.

Durand, B., Monin, J.C., 1980. Elemental analysis of kerogens. In: Durand B. (Ed.), Kerogen; Insoluble Organic Matter from Sedimentary Rocks. Technip, Paris, pp.113- 142.

Durand, B., Nicaise, G., 1980. Procedures for kerogen isolations. In: Durand, B. (ed.), Kerogen. Technip, Paris, pp. 35-53

Edwards, A.D., Bignell, R., 1988. Nine major play types recognized in salt basin. Oil and Gas Journal 86, 55-58.

Espitalié, J., Laporte, J.L., Madec, M., Marquis, F., Leplat, P., Paulet, J., Boutefeu, A., 1977. Méthode rapide de caractérisation de roches mères, de leur potentiel pétrolier et de leur degré d'évolution. Revue de l'Institut Français du Pétrole 32, $23-42$.

Espitalié, J., Deroo, G., Marquis, F., 1985. La pyrolyse Rock-Eval et ses applications. Partie I. Revue de l'Institut Français du Pétrole 40, 563-579.

Espitalié, J., Deroo, G., Marquis, F. 1986. La pyrolyse Rock-Eval et ses applications. Partie III. Revue de l'Institut Français du Pétrole 41, 73-89.

Fetter, M., De Ros, L. F., Bruhn, C.H.L., 2009. Petrographic and seismic evidence for the depositional setting of giant turbidite reservoirs and the paleogeographic evolution of Campos Basin, offshore Brazil. Marine and Petroleum Geology 26, 824-853.

Gelin, F.,Boogers, I., Noordeloos, A.A.M., Sinninghe Damsté, J.S., Hatcher P.G., de Leeuw J.W., 1996. Novel, resistant microalgal polyethers: An important sink of organic carbon in the marine environment? Geochimica et Cosmochimica Acta 60, 1275-1280. 
Goth, K., de Leeuw, J.W., Puttmann, W., Tegelaar, E.W., 1988. Origin of Messel Oil Shale kerogen. Nature 336, 759-761.

Hoefs, M.J.L., Sinninghe Damsté, J. S., de Lange, G. J., de Leeuw, J. W., 1998. Changes in kerogen composition across an oxidation front in Madeira Abyssal Plain turbidites as revealed by pyrolysis GC-MS. Proceedings of the Ocean Drilling Program, Scientific Results 59, 591-607.

Holtvoeth, J., Wagner, T., Horsfield, B., Schubert, C., WandLate, U., 2001. Quaternary supply of terrigenous organic matter to the Congo deep-sea fan (ODP site 1075): implications for equatorial African paleoclimate. Geo-marine letter 21, 23-33

Horsfield, B., Bharati, S., Larter, S.R., Leistner, F., Littke, R., Schenk, H.J., Dypvik, H., 1992. On the atypical petroleum generating characteristics of alginite in the Cambrian alum shale. In: Schidlowski, M., Golubic, S., Kimberley, M.M., McKirdy, D.M., Trudinger, P.A. (Eds.), Early Organic Evolution: Implications for Mineral and Energy Resources. Springer-Verlag, Berlin, pp. 257-266.

Lafargue, E., Marquis, F., Pillot, D., 1998, Rock-Eval 6 applications in hydrocarbon exploration, production and soils contamination studies. Oil \& Gas Science and Technology- Revue de l'Institut Français du Pétrole 53, 421-437.

Largeau, C., Casadevall, E., Kadouri, A., Metzger, P., 1984. Formation of Botryococcus braunii kerogens. Comparative study of immature Torbanite and of the extant alga Botryococcus braunii.. In: Schenck, P.A., de Leeuw, J.W., Lijmbach, G.W.M. (Eds.), Advances in Organic Geochemistry 1983, Organic Geochemistry, vol. 6. Pergamon Press, Oxford, pp. 327-332.

Largeau, C., Derenne, S., Casadevall, E., Kadouri, A., Sellier, N., 1986. Pyrolysis of immature Torbanite and the resistant biopolymer (PRB A) isolated from extant alga Botryococcus braunii. Mechanism of formation and structure of Torbanite. In: Leythaeuser, D., Rullkötter, J. (Eds.), Advances in Organic Geochemistry, 1985. Pergamon Press, Oxford, pp. 1023-1032.

Lindblom, S., Järnberg, U., 2004. Organic geochemistry of lipids in marine sediments in the Canary Basin: Implications for origin and accumulation of organic matter. In Hill R.J., Leventhal J., Aizenshtat Z., Baedecker M.J., Claypool G., Eganhouse, R. Goldhaber M. and Peters K. (Eds.), Geochemical Investigations in Earth and Space Science: A Tribute to Isaac R. Kaplan. The Geochemical Society, Publication n 9, 409-423. Elsevier,

Lopez, M., 2001. Architecture and depositional pattern of the Quaternary deep-sea fan of the Amazon. Marine and Petroleum Geology 18, 479-486. 
Mansurbeg, H., Morada, S., Salemc, A., Marfild, R., El-ghalie, M.A.K., Nystuenf, J.P., Cajad, M.A., Amorosig, A., Garciah, D., La Iglesiai, A., 2008. Diagenesis and reservoir quality evolution of palaeocene deep-water, marine sandstones, the Shetland-Faroes Basin, British continental shelf. Marine and Petroleum Geology 25, 514-543.

Marchand, C., Lallier-Vergès, E., Baltzer, F., 2003. The composition of sedimentary organic matter in relation to the dynamic features of a mangrove-fringed coast in French Guiana. Estuarine, Coastal and Shelf Science 56, 119-130.

McIver, R.D., 1975. Hydrocarbon occurrences from JOIDES Deep Sea Drilling Project cores. Proceedings Ninth World Petroleum Congress, vol. 2. Applied Science Publishers, London, pp. 269- 280.

Meyers, P.A., 1994. Preservation of elemental and isotopic source identification of sedimentary organic matter. Chemical Geology 114, 289-302.

Meyers, P.A., Silliman, J., Shaw, T.J., 1996. Effects of turbidity flows on organic matter accumulation, sulfate reduction, and methane generation in deep-sea sediments on the Iberia Abyssal Plain. Organic Geochemistry 25, 69-78.

Ourisson, G., Albrecht, P., Rohmer, M., 1979. The hopanoids: palaeochemistry and biochemistry of a group of natural products. Pure and Applied Chemistry 51, 709-729.

Peters, K. E., 1986. Guidelines for evaluating petroleum source rock using programmed pyrolysis. American Association of Petroleum Geologists Bulletin 70, 318-329.

Pichevin, L., Bertrand, P., Boussafir, M., Disnar, J.-R., 2004. Organic matter accumulation and preservation controls in a deep-sea modern environment: an example from Namibian Slope sediments. Organic Geochemistry 35, 543-599.

Piriou, S., 2006. Palynostratigraphie dans l'intervalle Oligocène-Miocène du domaine tropical ouest-africain - Analyse palynologique haute résolution de l'éventail sous-marin chattien du bassin du Bas-Congo. Thèse de l'Université de Bordeaux I.

Saiz-Jimenez, C., de Leeuw, J.W., 1986. Lignin pyrolysis products: their structures and their significance as biomarkers. Organic Geochemistry 10, 869-876.

Séranne, M., Séguret, M., Fauchier, M., 1992. Seismic super-units and post-rift evolution of the continental passive margin of southern Gabon. Bulletin de la Société Géologique de France 163, 135-146.

Stow D.A.V., Huc, A.Y., Brertrand, P., 2001. Depositional processes of black shales in deep water. Marine and Petroleum Geology 8, 491-498.

Tissot, B.P., Welte, D.H. 1984. Petroleum Formation and Occurrence. Springer, Berlin. 699 pp. 
Tyson, R.V., 1995. Sedimentary Organic Matter: Organic Facies and Palynofacies. Chapman \& Hall, London, 615 pp.

Wakeham, G., Lee, C., Hedges, J. I., Hernes P. J., Peterson, M. L., 1997. Molecular indicators of diagenetic status in marine organic matter. Geochimica et Cosmochimica Acta 61, 5363-5369.

Watanabe, H., Akiyama, M., 1998. Characterization of organic matter in the Miocene turbidites and hemipelagic mudstones in the Niigata oil field, central Japan. Organic Geochemistry 29, 605-611.

Zink, K.G., Furtado A.L.S., Casper P., Schwark, L., 2004. Organic matter composition in the sediment of three Brazilian coastal lagoons - District of Macaé, Rio de Janeiro (Brazil). Annals of the Brazilian Academy of Sciences 76, 29-47. 


\section{Captions of figures and tables}

Fig.1. Schematic cross-section of Angola margin redrawn from Philippe (1999). The wells are located between two ridges of salt in the outer part of the extension domain of the margin. The studied stratigraphic interval corresponds to upper Oligocene turbiditic facies.

Fig. 2. General map showing location of block 17 offshore Angola and distribution of the oil fields in Oligocene and Miocene turbiditic facies. The wells come from the Girassol, Lirio and Cravo oilfields.

Fig. 3. Location of 15 kerogens extracted from selected samples of different wells in a van Krevelen diagram and modified van Krevelen diagram (HI-OI) indicating a mixture of Type II and III OM in the Chattian fine-grained sediments of the Angola margin.

Fig. 4. Microphotographs of palynofacies of the Chattian fine-grained sediments of the Angola margin. a: Amorphous organic matter (AOM) with small ligno-cellulose debris (sample GIR 117-28 - TOC: 1.62\% - HI: 248 mg HC/g TOC). b: AOM with small black woody needle, large orange ligno-cellulose debris and numerous pyritic crystals (sample GIR IS3-4 - TOC: 1.74\% - HI: $241 \mathrm{mg} \mathrm{HC/g} \mathrm{TOC).} \mathrm{c:} \mathrm{Cuticle} \mathrm{fragments} \mathrm{with} \mathrm{stomatal} \mathrm{outline.} \mathrm{d:}$ partly-gelified ligno-cellulosic debris on which vegetal fibre are still discernible. e: gelified AOM. f: same view under UV showing intense fluorescence. g: "amorphised" higher plant debris (plant fibres are still visible) and h: same view under UV showing dull fluorescence (scale bar $100 \mu \mathrm{m}$ for all photomicrographs).

Fig. 5. Examples of partial reconstituted Total Ion Current (TIC) chromatogram of pyrolysates of selected kerogen concentrates from Chattian sediments off Angola.

Fig. 6. Distribution of $n$-alkanes and $n$-alkenes issued from the pyrolysates of kerogen extracted from selected samples of the different studied wells.

Fig. 7. Example of partial reconstituted chromatogram of products of thermochemolysis with TMAH of a kerogen sample from the Chattian off Angola (sample GIR 117-23). Black circles and "L" designate Fatty acid methyl esters (FAMEs) and lignin-derived compounds, respectively.

\section{Table 1}

- Selected wells and number of samples of the Chattian fine-grained sediments from Angola margin.

\section{Table 2}

- Bulk geochemical parameters from Rock-Eval pyrolysis of 216 samples from Chattian finegrained sediments from Angola margin. 


\section{Table 3}

- Bulk elemental analysis of 15 kerogen concentrates selected fromdifferent wells, corrected elemental analysis from pyrite and ash contents and calculated atomic ratios.

\section{Table 4}

- Relative abundance of main compounds in pyrolysates of 15 kerogen concentrates ${ }^{\mathrm{a}}$. 
wsw

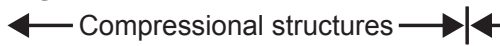

Oligocene 崖萬萬

ENE

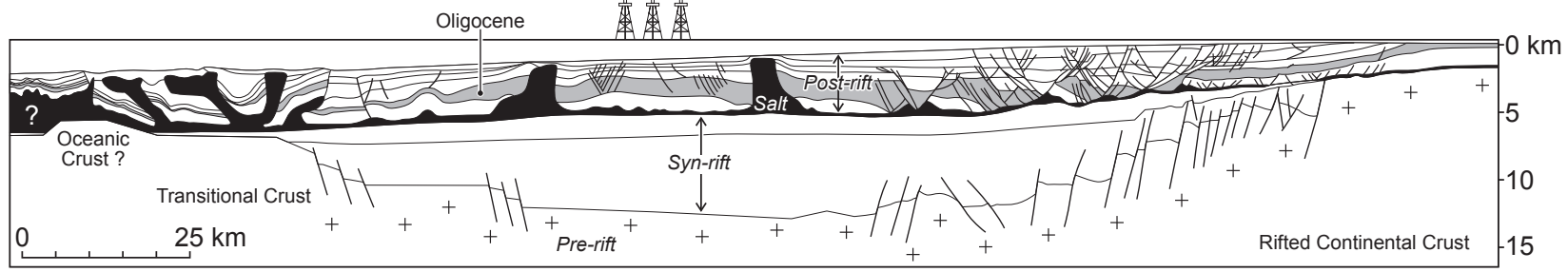




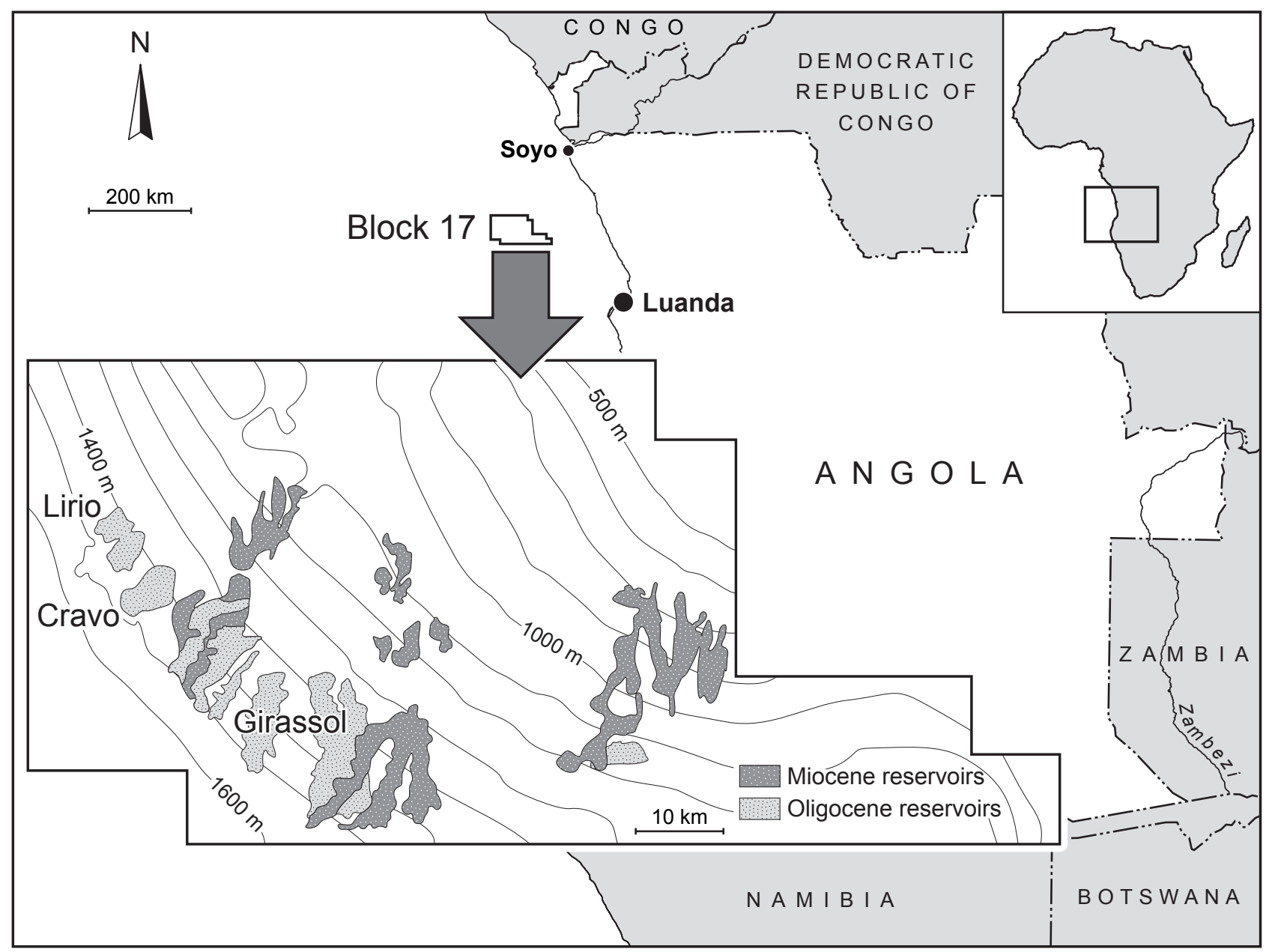



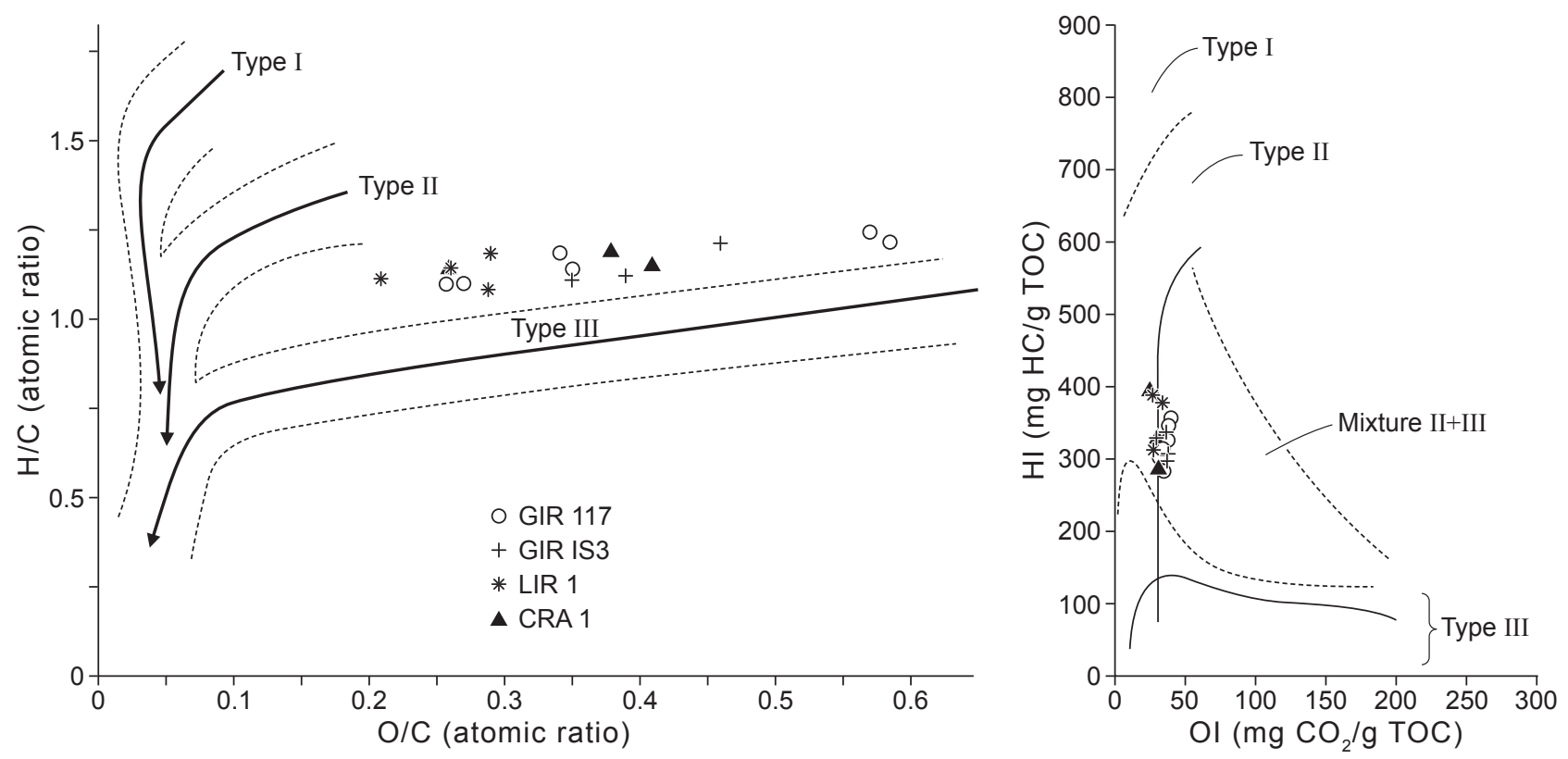

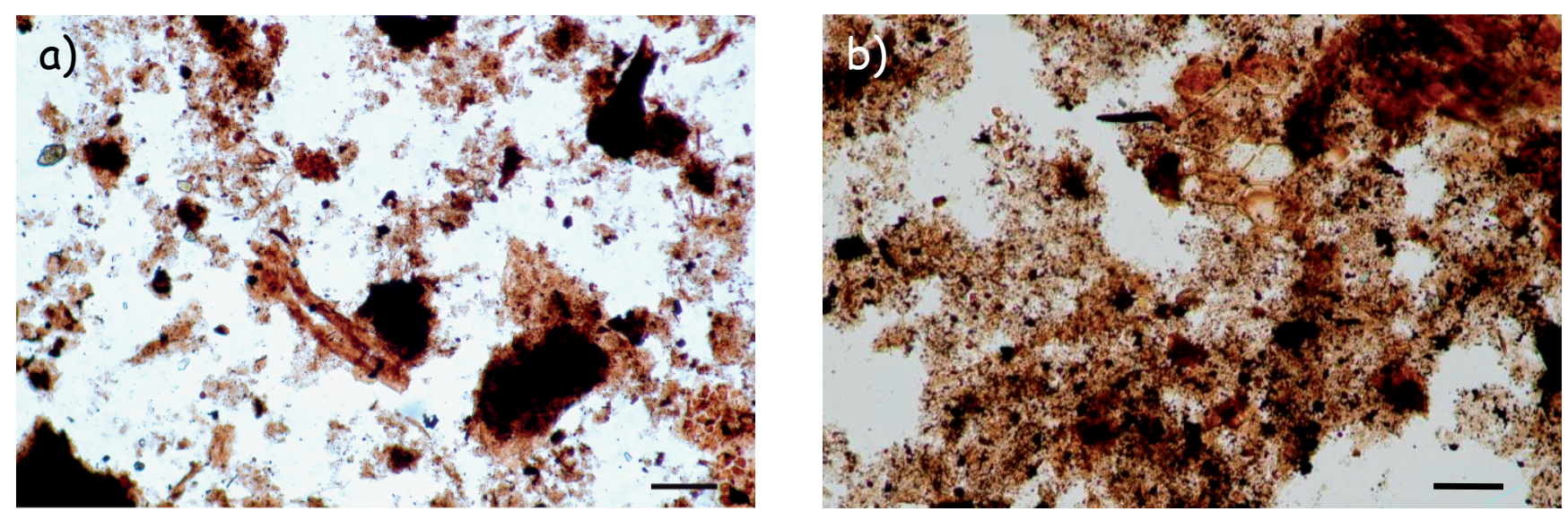

c)
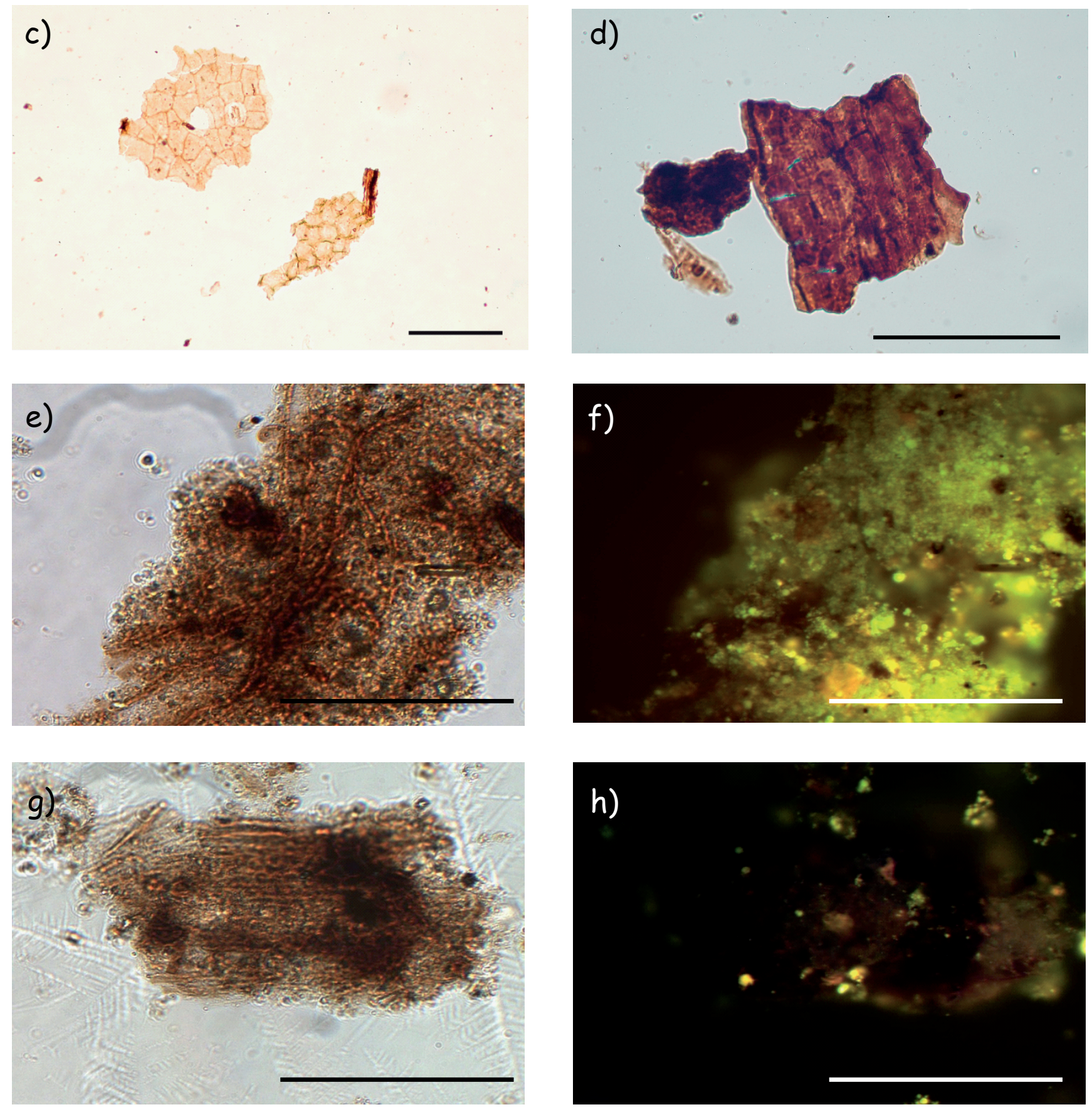

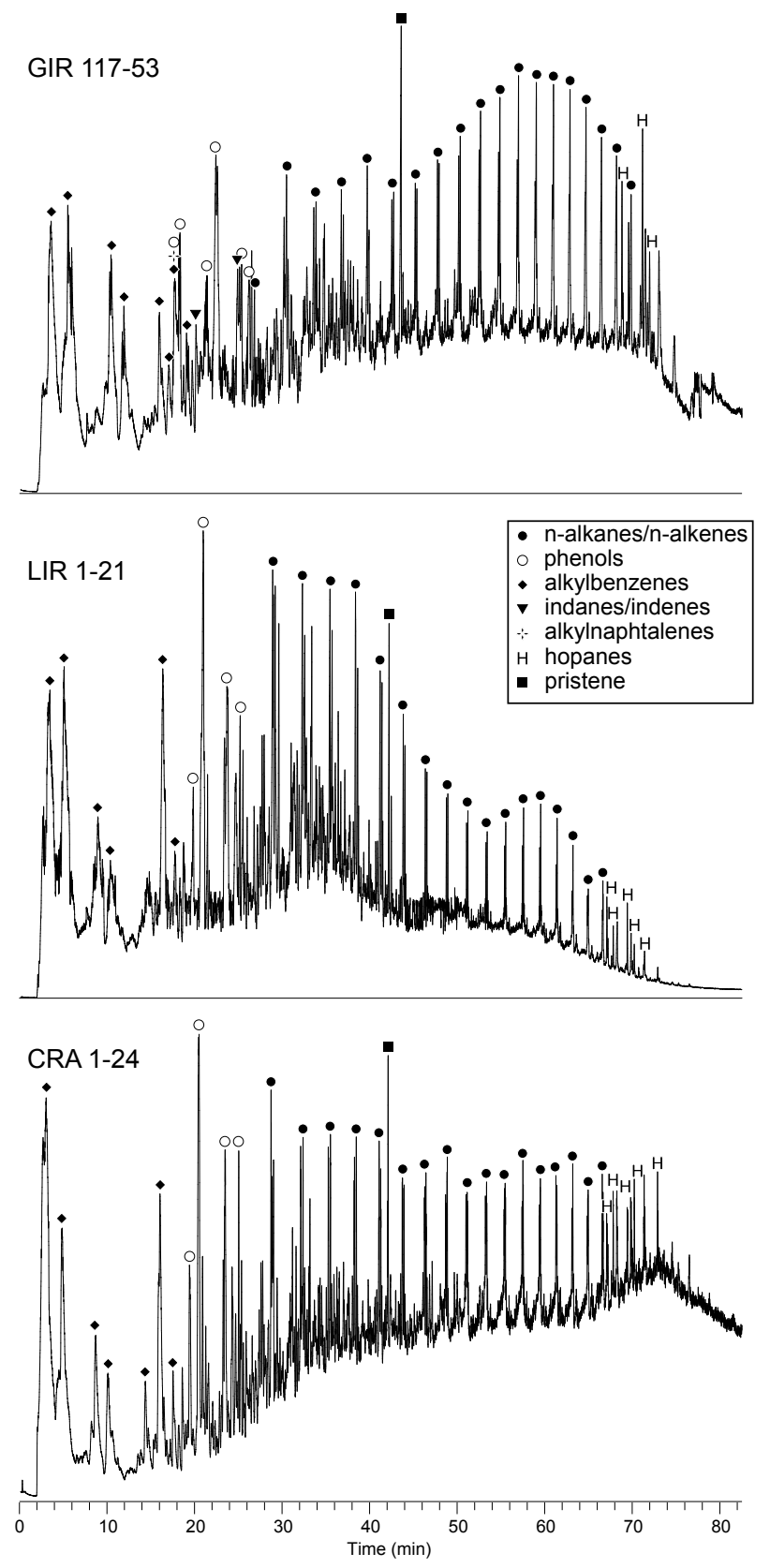


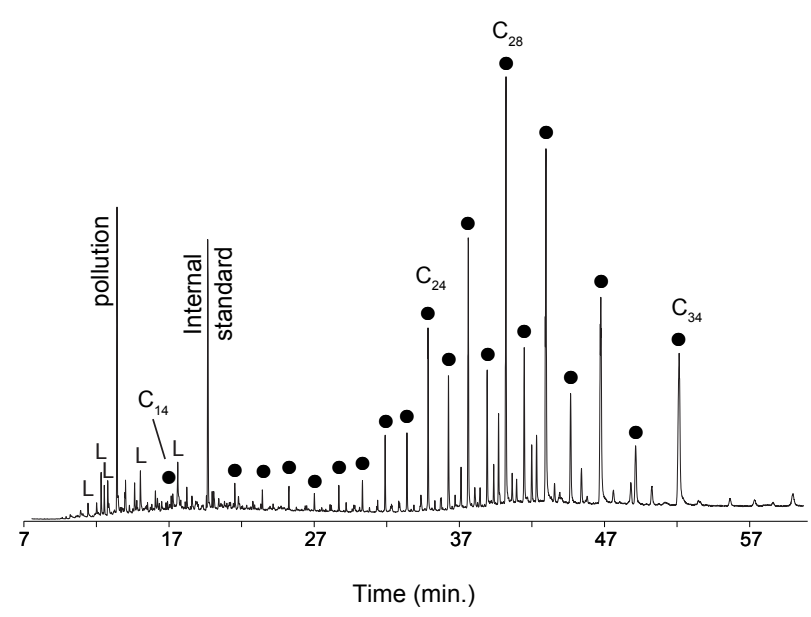




\begin{tabular}{lccc}
\hline Wells & $\begin{array}{c}\text { Number of } \\
\text { studied samples }\end{array}$ & $\begin{array}{c}\text { Thickness of studied } \\
\text { interval } \\
\text { (m) }\end{array}$ & $\begin{array}{c}\text { Average spacing } \\
\text { between samples } \\
\text { (m) }\end{array}$ \\
\hline Girassol 117 (GIR117) & 70 & 121.4 & 1.73 \\
Girassol IS3 (GIRIS3) & 31 & 24.5 & 0.79 \\
Lirio 1 (LIR1) & 72 & 69.0 & 0.96 \\
Cravo 1 (CRA1) & 43 & 25.5 & 0.59 \\
\hline
\end{tabular}

Tab. 1 - Selected wells and number of samples studied in the Chattian fine-grained sediments of the Angola margin.

\begin{tabular}{lcccc}
\hline Wells & $\begin{array}{c}\text { Number of } \\
\text { studied } \\
\text { samples }\end{array}$ & $\begin{array}{c}\text { TOC } \\
(\%) \\
\text { [average] }\end{array}$ & $\begin{array}{c}\text { Tmax } \\
\left({ }^{\circ} \mathrm{C}\right) \\
\text { [average] }\end{array}$ & $\begin{array}{c}\text { HI } \\
\text { (mg HC/g TOC) } \\
\text { [average] }\end{array}$ \\
\hline Girassol 117 (GIR 117) & 70 & $0.39-3.99$ & $400-435$ & $57-381$ \\
& & {$[1.30]$} & {$[427]$} & {$[189]$} \\
Girassol IS3 (GIR IS3) & 31 & $0.54-1.74$ & $414-434$ & $88-317$ \\
Lirio 1 (LIR 1) & & {$[1.00]$} & {$[426]$} & {$[186]$} \\
Cravo 1 (CRA 1) & 72 & $0.58-2.54$ & $404-437$ & $34-331$ \\
& 43 & {$[1.40]$} & {$[428]$} & {$[180]$} \\
& & $0.82-3.71$ & $404-434$ & $31-337$ \\
\hline
\end{tabular}

Tab. 2 - Bulk geochemical parameters issued from Rock-Eval pyrolysis of 216 samples from the Chattian fine-grained sediments of the Angola margin.

\begin{tabular}{|c|c|c|c|c|c|c|c|c|c|c|c|c|c|c|c|c|}
\hline Samples & C & H & $\mathbf{O}$ & $\mathbf{N}$ & $S_{\text {tot }}$ & Fe & $\mathrm{FeS}_{2}$ & $S_{\text {org }}$ * & C & $\mathbf{H}$ & $\mathbf{O}$ & $\mathbf{N}$ & Sorg & $\mathrm{H} / \mathrm{C}$ & $\mathrm{O} / \mathrm{C}$ & $\mathrm{N} / \mathrm{C}$ \\
\hline GIR117-28 & 28.84 & 2.84 & 13.16 & 1.15 & 6.06 & 5.97 & 12.79 & 0.00 & 62.71 & 6.18 & 28.61 & 2.50 & 0.00 & 1.18 & 0.34 & 0.034 \\
\hline GIR117-53 & 49.20 & 4.45 & 17.16 & 1.95 & 5.42 & 3.25 & 6.96 & 1.71 & 66.07 & 5.98 & 23.04 & 2.62 & 2.29 & 1.09 & 0.26 & 0.034 \\
\hline GIRIS3-4 & 26.05 & 2.43 & 13.59 & 0.95 & 24.51 & 20.59 & 44.12 & 0.98 & 59.21 & 5.52 & 30.89 & 2.16 & 2.22 & 1.12 & 0.39 & 0.031 \\
\hline GIRIS3-11 & 27.27 & 2.52 & 12.72 & 0.91 & 11.85 & 3.06 & 6.56 & 8.35 & 52.67 & 4.87 & 24.57 & 1.76 & 16.13 & 1.11 & 0.35 & 0.029 \\
\hline LIR1-21 & 23.51 & 2.32 & 9.14 & 1.28 & 28.56 & 23.42 & 50.19 & 1.79 & 61.8 & 6.10 & 24.02 & 3.36 & 4.72 & 1.18 & 0.29 & 0.047 \\
\hline LIR1-55 & 47.56 & 4.37 & 13.23 & 2.23 & 12.50 & 9.63 & 20.64 & 1.49 & 69.04 & 6.34 & 19.21 & 3.24 & 2.17 & 1.10 & 0.21 & 0.040 \\
\hline LIR1-63 & 34.91 & 3.14 & 13.33 & 1.69 & 17.18 & 14.28 & 30.60 & 0.86 & 64.73 & 5.82 & 24.72 & 3.13 & 1.59 & 1.08 & 0.29 & 0.041 \\
\hline CRA1-2 & 21.18 & 2.10 & 10.61 & 1.02 & 31.01 & 26.24 & 56.23 & 1.02 & 58.95 & 5.84 & 29.53 & 2.84 & 2.84 & 1.19 & 0.38 & 0.041 \\
\hline CRA1-24 & 37.54 & 3.57 & 13.07 & 1.66 & 16.46 & 15.84 & 33.94 & 0.00 & 67.23 & 6.39 & 23.41 & 2.97 & 0.00 & 1.14 & 0.26 & 0.038 \\
\hline CRA1-35 & 19.99 & 1.92 & 11.04 & 1.10 & 27.58 & 21.79 & 46.69 & 2.68 & 54.43 & 5.23 & 30.06 & 3.00 & 7.29 & 1.15 & 0.41 & 0.047 \\
\hline
\end{tabular}

Tab. 3 - Bulk elemental analyses of 15 kerogen concentrates selected in the different wells, corrected elemental analyses from the pyrite and ash contents and calculated atomic ratios. 


\begin{tabular}{|c|c|c|c|c|c|c|c|c|c|c|c|c|c|c|c|c|}
\hline \multirow[t]{2}{*}{$\mathrm{m} / \mathbf{z}$} & \multirow[t]{2}{*}{ Compound } & \multicolumn{5}{|c|}{ GIR 117} & \multicolumn{3}{|c|}{ GIR IS3 } & \multicolumn{4}{|c|}{ LIR 1} & \multicolumn{3}{|c|}{ CRA 1} \\
\hline & & 3 & 23 & 28 & 32 & 53 & 4 & 11 & 29 & 3 & 21 & 55 & 63 & 2 & 24 & 35 \\
\hline 78 & Benzene & 100 & 50 & 58 & 60 & 54 & 88 & 92 & 100 & 44 & 81 & 37 & 59 & 86 & 100 & 94 \\
\hline 92 & Toluene ( $\mathrm{C}_{1}$-benzene) & 79 & 40 & 57 & 56 & 43 & 76 & 78 & 60 & 45 & 74 & 48 & 66 & 74 & 45 & 68 \\
\hline 94 & Phenol & 43 & 27 & 35 & 28 & 30 & 38 & 53 & 21 & 28 & 27 & 24 & 29 & 34 & 38 & 41 \\
\hline 106 & $\mathrm{C}_{2}$-benzenes & 94 & 55 & 70 & 77 & 62 & 100 & 100 & 72 & 56 & 62 & 44 & 24 & 100 & 43 & 68 \\
\hline 108 & $\mathrm{C}_{1}$-phenol & 55 & 48 & 58 & 38 & 49 & 67 & 72 & 34 & 27 & 51 & 51 & 47 & 50 & 50 & 63 \\
\hline 116 & Indene & 10 & 6 & 8 & 9 & 7 & 9 & 12 & 9 & 6 & 9 & 6 & 6 & 6 & 5 & 8 \\
\hline 118 & Indane & 7 & 3 & 4 & 5 & 5 & 7 & 9 & 5 & 3 & 5 & 3 & 4 & 4 & 3 & 5 \\
\hline 120 & $\mathrm{C}_{3}$-benzenes & 52 & 27 & 30 & 33 & 35 & 45 & 50 & 57 & 32 & 48 & 15 & 24 & 27 & 21 & 33 \\
\hline 122 & $\mathrm{C}_{2}$-phenols & 32 & 13 & 33 & 22 & 24 & 37 & 46 & 22 & 21 & 34 & 34 & 27 & 25 & 26 & 31 \\
\hline 128 & Naphtalene & 5 & 2 & 5 & 4 & nd & 5 & 7 & 4 & 3 & 5 & 4 & 3 & 5 & 4 & 7 \\
\hline 130 & $\mathrm{C}_{1}$-indenes & 7 & 5 & 6 & 5 & 10 & 13 & 11 & 10 & 5 & 19 & 8 & 2 & 9 & 7 & 11 \\
\hline 132 & $\mathrm{C}_{1}$-indanes & 14 & 8 & 10 & 8 & 6 & 14 & 15 & 7 & 5 & 8 & 8 & 5 & 6 & 6 & 8 \\
\hline 134 & $\mathrm{C}_{4}$-benzenes & 24 & 12 & 12 & 15 & 15 & 22 & 23 & 24 & 8 & 13 & 7 & 13 & 16 & 13 & 19 \\
\hline 136 & $\mathrm{C}_{3}$-phenols & 8 & 7 & 7 & 8 & 5 & 13 & 21 & 11 & 8 & 5 & 13 & 12 & 9 & 13 & 14 \\
\hline 142 & $\mathrm{C}_{1}$-naphtalenes & 5 & 3 & 5 & 8 & 5 & 6 & 15 & 2 & 9 & 21 & 6 & 4 & 3 & 10 & 7 \\
\hline 144 & $\mathrm{C}_{2}$-indenes & 16 & 11 & 12 & 8 & 14 & 24 & 28 & 24 & 12 & 30 & 7 & 10 & 17 & 19 & 22 \\
\hline 146 & $\mathrm{C}_{2}$-indanes & 4 & 3 & 3 & 6 & 3 & 5 & 9 & 6 & 2 & 7 & 13 & 4 & 3 & 4 & 4 \\
\hline 150 & $\mathrm{C}_{4}$-phenols & 4 & 4 & 4 & 3 & 7 & 5 & 4 & nd & 12 & 15 & 47 & 1 & 8 & 6 & nd \\
\hline 156 & $\mathrm{C}_{2}$-naphtalenes & 26 & 17 & 18 & 12 & 13 & 5 & 9 & 10 & 26 & 31 & 15 & 11 & 12 & 14 & 19 \\
\hline 158 & $\mathrm{C}_{3}$-indenes & 3 & 6 & 4 & 3 & 3 & 5 & 6 & 9 & 12 & 20 & 5 & 1 & 6 & 7 & 6 \\
\hline 160 & $\mathrm{C}_{3}$-indanes & nd & 4 & nd & nd & 4 & nd & nd & nd & 3 & 6 & 7 & 2 & 4 & 3 & 4 \\
\hline 166 & Fluorene & nd & nd & nd & nd & nd & nd & nd & nd & 2 & 2 & 7 & nd & 1 & 1 & 2 \\
\hline 170 & $\mathrm{C}_{3}$-naphtalenes & 21 & 15 & 16 & 7 & 7 & 12 & 15 & 7 & 25 & 22 & 17 & 7 & 9 & 12 & 13 \\
\hline 178 & Phenanthrene/anthracene & 2 & 1 & 2 & 1 & 1 & nd & nd & nd & 4 & 1 & 2 & 1 & 0 & 1 & 2 \\
\hline 180 & $\mathrm{C}_{1}$-fluorene & nd & nd & nd & nd & nd & nd & nd & nd & 3 & 5 & 2 & 3 & 4 & 5 & 5 \\
\hline 184 & $\mathrm{C}_{4}$-naphtalenes & 4 & 4 & 4 & 3 & 3 & 2 & 4 & 1 & 2 & 3 & 3 & nd & 3 & 3 & 2 \\
\hline 192 & $\mathrm{C}_{1}$-phenanthrene/anthracene & 2 & 3 & 3 & 2 & 3 & 3 & 6 & nd & 7 & 2 & 6 & 3 & 3 & 4 & 6 \\
\hline \multirow[t]{5}{*}{206} & $\mathrm{C}_{2}$-phenanthrene/anthracene & 3 & 8 & 5 & nd & 4 & 4 & 4 & nd & 4 & 2 & 6 & 3 & 3 & 6 & 9 \\
\hline & $n$-Alcanes $\left(\mathrm{C}_{9}-\mathrm{C}_{33}\right)$ & 59 & 100 & 100 & 100 & 100 & 45 & 87 & 26 & 100 & 87 & 100 & 100 & 64 & 80 & 90 \\
\hline & $n$-Alcenes $\left(\mathrm{C}_{12}-\mathrm{C}_{28}\right)$ & 60 & 81 & 89 & 75 & 81 & 46 & 67 & 25 & 98 & 100 & 83 & 98 & 78 & 83 & 100 \\
\hline & Pristenes & 11 & 12 & 11 & 9 & 10 & 5 & 7 & 4 & 15 & 13 & 8 & 12 & 10 & 8 & 9 \\
\hline & Hopanes $\left(\mathrm{C}_{27}-\mathrm{C}_{29}\right)$ & 8 & 14 & 15 & 21 & 20 & 3 & 11 & 1 & 11 & 11 & 46 & 17 & 15 & 11 & 19 \\
\hline
\end{tabular}

Tab. 4 - Relative abundance of the main compounds identified in pyrolysates of the 15 selected kerogen concentrates. The abundance is calculated as the surface of the identified compound (+ its isomers) normalized to the most intense peak of the series. nd : not determined. 